\title{
Koulutuksen globaali ja paikallinen merkitys
}

ARI ANTIKAINEN

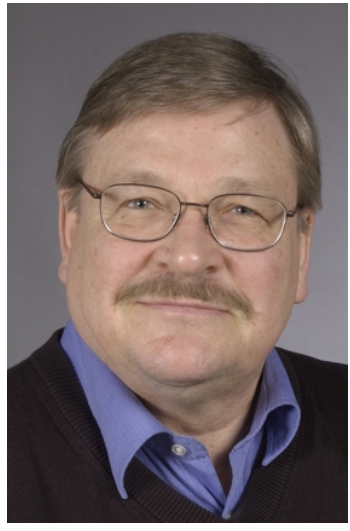

Väitän, että koulutuksella yhteiskunnallisena instituutiona ja toimintana on kaksi puolta: globaali tai yleinen puolensa ja paikallinen tai erityinen puolensa (Izquierdo \& Minguez 2003). Globalisaation myötä ja siis maailmanjärjestelmän taloudellisesti määrittyneenä osana koulutus on muodostunut tieteen ja tekniikan tavoin hyvin yhdenmukaiseksi järjestelmäksi maapallon kaikissa osissa. Lisäksi koulutus kasautuu muutoinkin runsaat resurssit omaaville ryhmille ja yksilöille eli korkeatuloisille ja usein korkeasti koulutetuille ja heidän lapsilleen. Siten koulutus on mukana yhteiskunnallisten erojen ja eriarvoisuuden muodostumisessa ja jatkumisessa sukupolvesta toiseen. Tämän puolen koulutuksesta tunnemme hyvin myös median välittämänä, joskin media vielä usein liioittelee tai yksinkertaistaa koulutuksen sosiaalisen periytymisen tapahtumaa.

Toisaalta koulutuksella on ainakin kulttuurisesti toinen paikallinen ja erityinen puolensa. Sitä voidaan myös luonnehtia monikulttuurisuuden käsitteen avulla. Koulutusta voidaan käyttää voimavarojen luojana pyrittäessä aktiivisesti erilaisiin yhteiskunnallis-poliittisiin tai kulttuurisiin tavoitteisiin kuten tasa-arvoon, demokratiaan tai suvaitsevaisuuteen ja moniarvoisuuteen. Koulutuksella on yhteiskunnallisesta kontekstista riippuen suhteellista itsenäisyyttä muuhun yhteiskuntaan ja yhteiskunnalliseen vallankäyttöön. Lisäksi yksilöllistymiskehityksen kautta tämä koulutuksen käyttö monenlaisiin tarkoituksiin koskee kaikkia.

Esittämästäni näkökulmasta paikallisuus voidaan siis käsittää koulutuksen kehittämisen voimavarana. Aikuiskoulutuksessa tämä on ilmeisintä ja ilmenee esimerkiksi puheena koulutuksen "räätälöimisestä" sen kohderyhmälle. Käyttämäni paikallisuuden käsite on kuitenkin yleisempi ja laajempi niin, että esimerkiksi suomalaisten aikuisten erinomainen menestys Kansainvälisessä aikuisten lukutaitotutkimuksessa (IALS) selittyy ja liittyy epäilemättä meidän kansalliseen ja laajemmin pohjoismaiseen aikuiskoulutuksen malliimme eli kansainvälisesti korkeaan aikuiskoulutukseen osallistumisen tasoon, korkeaan julkisen rahoituksen osuuteen ja tasoon sekä korkeaan yleissivistävien tai harrastuspohjaisten opintojen osuuteen (Tuijnman \& Hellström 2001). Aikuiskoulutuksen kasvu on tapahtunut ammatillisessa aikuiskoulutuksessa, mutta yhtä tärkeä on havaita, että yleissivistäviin tai harrastuspohjaisiin opintoihin osallistumisen taso on säilynyt samana (Tuomisto 1998; Taulukko 1.). 
Taulukko 1. Aikuiskoulutukseen osallistuminen vuosina 1980, 1990, 1995 ja 2000 (18-64-vuotiaat) (\%). (Tilastokeskus, Aikuiskoulutustutkimukset.; Lehtonen \& Tuomisto 1973; **Tuomisto 1998.)

* ja ** eivät ole täysin vertailukelpoisia myöhempien vuosien kanssa, mutta kertovat suuruusluokan

\begin{tabular}{|c|c|c|c|c|c|c|}
\hline \multirow[t]{2}{*}{ Vuosi } & \multirow{2}{*}{\multicolumn{2}{|c|}{$\begin{array}{l}\text { Työhön tai ammattiin } \\
\text { liittyvä aikuiskoulutus } \\
\text { Työvoimasta Työllisistä }\end{array}$}} & \multicolumn{2}{|c|}{$\begin{array}{l}\text { Muu kuin työhön tai ammat- } \\
\text { tiin liittyvä aikuiskoulutus }\end{array}$} & \multicolumn{2}{|c|}{$\begin{array}{l}\text { Aikuiskoulutukseen yleensä } \\
\text { (tarkoituksesta riippumatta) }\end{array}$} \\
\hline & & & Väestöstä & Työllisistä & Väestöstä & Työllisistä \\
\hline $\begin{array}{l}1972^{*} \\
1980^{* *}\end{array}$ & & & $\begin{array}{l}13 \\
17\end{array}$ & & 32 & \\
\hline 1990 & 44 & 45 & 18 & 19 & 47 & 55 \\
\hline 1995 & 43 & 50 & 18 & 18 & 48 & 60 \\
\hline 2000 & 51 & 55 & 18 & 17 & 54 & 63 \\
\hline
\end{tabular}

Haluan korostaa sitä, että esittämästäni näkökulmasta koulutettujen sijoittuminen oppilaitoksensa tai yliopistonsa sijainti- ja vaikutusalueelle on siis globaali eikä paikallinen säännönmukaisuus. Tähän on kuitenkin syytä tehdä varaus: jos siihen liittyy myös paikallisen identiteetin muodostuminen, muuttuu se osaksi paikallistakin.

Globaali ja paikallinen ovat tietyllä tavoin väistämättä vuorovaikutuksessa ja täsmällisemmin dialektisessa suhteessa keskenään. Voin havainnollistaa tätä tulkinnallani Joensuun yliopiston alueellisten vaikutusten tulkintamallista (ks. KUVIO 1.; myös Antikainen ym. 2002, 44).

Kuviossa esitän yliopiston tehtävät Perttu Vartiaisen (Vartiainen \& Viiri 2002/2005) jaottelemana, ympäristön globaalin ja paikallisen puolen Michael Castellsin (1996) ajatteluun pohjautuen ja tuotoksen Pierre Bourdieun ajattelua soveltaen. Samantyyppisen mallin voinee esittää myös muiden oppilaitosten suhteesta ympäristöönsä.
Tähän teoretisointiin sijoittuu myös tutkimustyömme koulutuksen merkityksestä inmisten elämänkulussa ja elämäkerroissa (Oppiminen ja elämänhistoria 1996; Antikainen 2005).

\section{Koulutuksen ja oppimisen monet merkitykset}

Ajatus yhteiskunnan monikulttuuristumisesta ja yksilöllistymisestä on taustana myös oman tutkimusryhmäni koulutuksen ja oppimisen merkitystä selvittävissä tutkimuksissa (Antikainen 2004). Kiinnostukseni elämäkertatutkimukseen virisi siitä ajatuksesta, että yksilöiden kiinnittyminen yhteiskuntaan on muuttunut. Sosiologikaan ei voi enää kuvata yksilöitä yksinomaan sosiaalisten roolien kantajina, eivätkä roolit ja sosiaaliset identiteetit ole pysyviä. Siten elämäkertametodi, jossa kuunnellaan myös tutkittavien ääntä ja jossa tarkistetaan teoriaa ja käsitteistöä vuoropuhelussa tutkittavien kanssa, oli luon-

Kuvio 1. Teoreettinen luonnostelma yliopiston ja ympäristön vuorovaikutuksen tasoista. (Antikainen ym. 2002, 44.)

\begin{tabular}{|l|l|l|}
\hline Yliopisto: & Ympäristö: & Tuotos: \\
\hline $\begin{array}{l}\text { Alueelliseen innovaatio- } \\
\text { järjestelmään liittyvä } \\
\text { tutkimus- ja koulutus }\end{array}$ & globaali verkko\& aluetalous & inhimillinenpääoma \\
$\begin{array}{l}\text { Sivistykseen liittyvä akatee- } \\
\text { minen tutkimus ja koulutus }\end{array}$ & $\begin{array}{l}\text { mediakulttuuri\& paikallinen } \\
\text { minä }\end{array}$ & kulttuuri-pääoma \\
Yliopisto osana yhdyskuntaa & $\begin{array}{l}\text { paikallisyhteisö\& mon- } \\
\text { kulttuurinenhyvinvointi- } \\
\text { yhteiskunta }\end{array}$ & sosiaalinen/yhteisöpääoma \\
\hline
\end{tabular}


teva valinta tutkimuksen metodiksi ja siitä johdetuksi elämänhistorialliseksi lähestymistavaksi. Oppiminen ja elämänhistoria -kirjana (1996) ilmestyneen tutkimuksemme voi katsoa puhuvan koulutuksen ja oppimisen monien merkitysten olemassaolosta.

Sen tuloksia ja tulkintoja voi yrittää koota Erik Allardtin (1976) hyvinvoinnin ulottuvuuksia koskevan jäsennyksen avulla. Allardtin mukaan hyvinvointi ei koostu vain aineellisesta elintasosta (having), vaan myös ihmisten välisistä yhteisyyssuhteista (loving) ja itsensä toteuttamisen muodoista (being). Näihin yhteisyyssuhteisiin kuuluu jäsenyydet paikallisen yhteisön jäsenenä aina kansakunnasta kyläyhteisöön, perheen ja suvun jäsenyys sekä ystävyyssuhteet.

Itsensä toteuttaminen on taas mahdollisuuksien käyttämistä ja persoonallisuuden kehittämistä vastakohtana vieraantumiselle ja korvattavuudelle. Arvonanto, korvaamattomuus, poliittiset voimavarat ja kiinnostava tekeminen vapaa-aikana ovat keskeisiä itsensä toteuttamisen muotoja. Kaikkia osatekijöitä voidaan Allardtin mukaan tarkastella niin arvoina sinänsä kuin voimavaroina eli resursseina. On kiinnostavaa, miten lähelle having, loving ja being asettuvat nykykeskustelun inhimillisen pääoman, sosiaalisen pääoman ja kulttuurisen pääoman käsitteitä.

Elämässä selviytyminen niin aineellisesti kuin henkisestikin on tulkintani mukaan koulutuksen tai epävirallisemman oppimisen keskeinen merkitys yksilöille suomalaisessa kulttuurissa. Tämän havainnon ja tulkinnan sovellus olisi koulutuksesta tiedottaminen ja puhuminen tällä elämässä selviytymisen tai hienosti selviytymisen eetoksen kielellä.

Yhteisyyssuhteissa koulutuksen merkitys kansallisvaltion kansalaisuuden ja myös maakunnallisen alueyhteisön tai koulukaupungin jäsenyyden tarjoajana on ilmeinen ja tunnettu. Koulutus ei sitä tietysti yksin tuota, vaan opiskeluympäristö suhteessa muuhun sosiaaliseen ympäristöön. Muutoinkin koulutusjärjestelmä voidaan Jarmo Houtsosen (2000) tulkinnan mukaan nähdä tyypillisten identiteettimallien tai sosiaalisen minän mallien tarjoajana. Siten on myös koulutuspoliittinen kysymys pohtia, mitä käsityksiä itsestä eli mitä identiteettejä koulutus kulloinkin tuottaa.

Itsensä toteuttamisen suhteen ihmiset näyttävät jakaantuvan kahteen pääryhmään. Ammattikoulutuksen hankkineet arvostavat usein teke- mistä niin työssä kuin vapaa-aikana esimerkiksi lukemisen sijaan ja katsovat yliopistokoulutuksen liittyvän selvemmin statuksen hankkimiseen. Sittemmin olemme havainneet, että tällainen jako on laajempi ja syvempi kuin harrastuksia koskeva. Hilkka Mehtätalon (2005) tutkimus SAK:n luottamushenkilöiden oppijaidentiteetistä kertoo sen vakuuttavasti. Ainakin ammattikoulun käyneet ja vain kansa- tai peruskoulun käyneet luokittelevat ihmiset kahteen ryhmään "lukijoihin" tai "teoreettisesti" suuntautuneisiin ja "tekijöihin" tai "käytäntöön" suuntautuneisiin. Yleisesti tämä itseluokituksiin eli identiteetteihin ellei peräti habituksiin perustuva jako on ensinnä aivan liian jyrkkä ollakseen täysin 'totta', ja toiseksi joka tapauksessa kulttuuri- ja koulutuspoliittisesti kyseenalainen tai haitallinen. Sen sijaan olisi yleisesti perusteltua pyrkiä ylittämään tämän jaon rajat myös opetuksessa ja oppimisessa.

Paikallisesti sitä voidaan kuitenkin käyttää "räätälöinnissä" hyväksi. Työkoulu nuorisolle ja työssä oppiminen ja näyttötutkinnot aikuisille ovat esimerkkejä "tekijöille" tai "käytäntöön" suuntautuneille rakennetuista opiskelumahdollisuuksista. Avoin yliopisto taas esimerkki "lukijoille" tai "teoriaan" suuntautuneille.

\section{Sivistyksen mahdollisuus}

Juha Kauppilan väitöskirja Sukupolvet, koulutus ja oppiminen: Tulkintoja koulutuksen merkityksestä elämänkulun rakentajana (2002) käsittelee suomalaisia koulutussukupolvia. Siinä tulee havainnollisesti esiin koulutuksen merkityksen muodostuminen yhteiskunnan suurten muutosten yhteydessä. Sodan ja niukan koulutuksen sukupolvelle koulutus oli lähinnä ihanteellinen tavoite, rakennemuutoksen ja kasvavien koulutusmahdollisuuksien sukupolvelle se oli ensisijaisesti väline ammattiuralla, ja nuorelle hyvinvoinnin ja monien koulutusvalintojen sukupolvelle koulutus oli paljolti hyödyke tai itsestäänselvyys.

1990-luvun lama - jota Kauppila ei enää käsittele - sitten ilmeisesti kyseenalaisti tietyn koulutuksen itsestäänselvyyden, mutta mahdollisesti vielä voimisti koulutuksen välineluonnetta. Kauppila keskustelee tästä välineellistymisen kasvusta huolestuneen oloisesti. Mielestäni hänen huolelleen on hyvät perusteet. Koulutuksen ymmärtäminen sivistyksenä ei ole vanhanaikais- 
ta, vaan kertoo sen miten koulutuksella on aina arvosisältö ja miten siitä on syytä keskustella ja sitä arvioida. Lisäksi ajattelen niin, että pelkät taloudelliset ja uratavoitteet eivät aina ole riittäviä koulutukseen motivoitumiselle. Tätä havainnollistan tuloksilla ja tulkinnoilla sukupuolen mukaisista eroista.

\section{Sukupuolen merkitys}

Joskus tuntuu, että Suomessa koulutuksella on sukupuoli. Siinä määrin ylivoimaisia naiset ovat koulutukseen osallistujina. Aikuiskoulutuksessa tämä on erityisen kiinnostavaa siitä syystä, että valtakunnallisen aikuiskoulutustutkimuksen mukaan koulutukseen osallistumisen taloudelliset ja ammatilliset hyödyt taas ovat osallistuville miehille selvästi naisia suuremmat.

Onko tämän takana naisten toisenlainen suhtautuminen koulutukseen? Päivi Kauppilan ja Mari Käyhkön(1996; 2005) mukaan tytöt suuntautuvat koulutukseen ilmaisullisemmin ja itseisarvoisemmin kuin välineellisemmin suuntautuvat pojat. Siis tytöillä ovat arvot ja tunteet mukana. Malli lienee omaksuttu jo lapsuuden perheessä.

Toki naisten aktiivisemmalle osallistumiselle löytää muitakin selityksiä. Ajatusleikkinä ainakin seuraavat: se liittyy naisten keskimäärin alistetumpaan asemaan työelämässä ja yhteiskunnassa samalla kun osallistuminen tapahtuu naisasian tai feminismin hengessä, se liittyy naisten keskimäärin runsaammin muutoksia tai siirtymiä sisältävään elämänkulkuun ja erityisesti siihen että lasten saaminen lykkää aikuiskoulutukseen menoa tai se liittyy naisten miehiä avoimempaan itseilmaisuun eli siihen että koulutukseen voidaan osallistua arvokkuutta tai kasvoja menettämättä.

\section{Työ ja koulutus}

Katja Komonen tutki väitöskirjassaan Koulutusyhteiskunnan marginaalissa? Ammatillisen koulutuksen keskeyttäneiden nuorten yhteiskunnallinen osallisuus (2001) ammattikoulun keskeyttäjien elämänkulkua ja kokemusmaailmaa. Nuoret olivat siis koulutuksen keskeyttäjiä eli englanniksi stop-outs eikä koulutuksen lopettajia eli drop-outs. Tulosten mukaan ryhmä ei ole yhtenäinen, vaan keskeyttämistä voidaan käyttää eri tilanteissa erilaisiin tarkoituksiin. Kiinnostava on Komosen havainto ja tulkinta, jonka mukaan nuoret voivat arvostaa koulutusta vaikka koulun arvo ja arvostus olisi murentunut ja että lähes kaikki nuoret arvostivat työtä. Työkokemukset olivat myös saattaneet osaa nuorista takaisin koulutuksen piiriin.

Komonen on jatkanut työtään Itä-Suomen työkouluhankkeessa. Tulkitsen työssä oppimisen yhtenä "paikallisena" ja vaihtoehtoisena sekä siten monikulttuurisuuden tunnustamisen suuntaisena koulutuksen järjestämisen mahdollisuutena. Se ei siten ole suinkaan vastakkainen edellä esitetyille ajatuksille sivistyksestä.

\section{Elämänkulun luonne ja koulutus}

Erja Mooren väitöskirja Pitkä opintie: Aikuisiällä suoritettu yliopistotutkinto ja koulutuksellisen elämänkulun muutos (2003) käsittelee aikuisiällä eli yli 30-vuotiaina aloitetun yliopistokoulutuksen ja suoritetun tutkinnon merkitystä. Tulkitsen Mooren tuloksia niin, että yliopisto-opinnot ovat tälle ryhmälle varsin yksilöllinen, ellei suorastaan yksinäinen hanke. Juhlapuheissa elinikäisen oppimisen hengessä elävät työyhteisöt eivät käytännössä niin ihanteellisia usein olekaan. Niinpä osa tutkittavista on joutunut salaamaan opiskelunsa työpaikallaan. Nyt he ovat varsin tyytyväisiä suorittamansa koulutuksen hyötyyn, joka ei suinkaan aina ole ollut taloudellinen.

Teoreettisesti erittäin kiinnostavaa on se, että tutkittavan ryhmän edustajien elämänkulku on ollut varsin vakaata. Juuri kun suuri osa tutkijoista on vakuuttunut siitä, että elämänkulun siirtymät, ellei yleensä muutoksen hallintaan pyrkivät elämäntilanteet, ovat aikuisten koulutukselle tai ainakin sen merkityksellistymiselle antoisin yhteys, Moore esittää poikkeavan tuloksen. Tosin Mooren tutkimassa ryhmässä on kyllä työhön "puutuminen" varsin yleistä. Se saa minut tulkitsemaan niin, että elämänkulun tasaisen tien eli myönteisten kokemusten ja menestymisen ja elämänkulun muutosten tien välissä on myös harmaa maasto, jolla voi olla omat erityispiirteensä (Hodkinson \& Sparkes 1997). Siis esimerkiksi siihen tapaan, että ryhmän on saanut liikkeelle työhön puutuminen ja liikkeelle lähtöä ei ole jarruttanut leimaavat kielteiset koulutus- ja työttömyyskokemukset, jotka tältä ryhmältä todella puuttuivat.

Olen yrittänyt tarjota näkökulmaa tai näkökulmia koulutuksen paikallisen tai ryhmäkoh- 
taisen merkityksen ymmärtämiseen. Paikallisella tarkoitan myös pohjoismaista ja suomalaista. Lopuksi haluan esittää myös ajatusleikinomaisia esimerkkejä siitä, miten ajatteluani voisi yrittää soveltaa Pohjois-Karjalan erityisoloihin.

Pohjois-Karjalan pitkät välimatkat ja harva asutus saattaisivat tarjota sopivan ympäristön ja soveltamiskohteen informaatioajan opetusteknologisten ratkaisujen kehittämiselle. Jos kehitystyöhön panostettaisiin niin, että ratkaisulla olisi yleisempää kysyntää, olisi oivallisesti yhdistetty paikallinen ja globaali.

Toisena esimerkkinä mieleeni tulee se, että Pohjois-Karjalasta puuttuvat monet aikuiskoulutuksen erityisoppilaitokset, kuten kielikoulut tai kirjoittajakoulut tai tanssikoulut tai vastaavat käden taitojen erityiskoulut. Näitä voi tarjota ja varmaan jo tarjoaa - yleisemmät oppilaitokset. Onko mahdollista ja tarpeen kehitellä aikuiskoulutuksen yhteistyön malleja, joilla olisi laajempaa käyttöä muuallakin? Maakunnan kattava koulutuskuntayhtymä tarjoaa siihen hyvät hallinnolliset mahdollisuudet. Muistutan vain, että avoimen yliopiston suomalainen malli tai sen olennainen osa rakennettiin aikoinaan täällä.

\section{Lähteet}

Allardt, E. (1976). Hyvinvoinnin ulottuvuuksia. WSOY.

Antikainen, A. (2004). Lyhyt tutkimusretki koulutuksen merkityksiin. Ostiensis, Joensuun yliopiston tiedotuslehti 1/2004.

Antikainen, A. (toim. 2005). Transforming a Learning Society: The Case of Finland. Bern: Peter Lang. ( ks. http://www.joensuu.fi/sosiologia/cscrejoe/)

Antikainen, A. ym. (2002). Joensuun yliopiston alueellisen vaikuttavuuden itsearviointiraportti. Joensuun yliopisto: Hallintoviraston raportteja ja selvityksiä 29.

Castells, M. (1996). The Rise of the Network Society. Oxford: Blackwell.

Hodkinson, P. \& Sparkes, A.C. (1997). Careership: a sociological theory of career decision making. British Journal of Sociology of Education 18, (1), 29-44.

Houtsonen, J. ym. (2000). Koulutus, elämänkulku ja identiteetti. Joensuun yliopisto: So- siologian laitoksen tutkimuksia 3.

Izquierdo, H.M. \& Minguez, A.M. (2003). Sociological Theory of Education in the Dialectical Perspective. In Torres, C. \& Antikainen, A. (eds.) The International Handbook on the Sociology of Education. Lanham-BoulderNew York-Oxford: Rowman \& Littlefield.

Kauppila, J. (2002). Sukupolvet, koulutus ja oppiminen. Joensuun yliopiston kasvatustieteellisiä julkaisuja 78. Väitöstutkimus.

Komonen, K. (2001). Koulutusyhteiskunnan marginaalissa? Ammatillisen koulutuksen keskeyttäneiden nuorten yhteiskunnallinen osallisuus. Joensuun yliopiston yhteiskuntatieteellisiä julkaisuja 47. Väitöstutkimus.

Käyhkö, M. \& Tuupanen, P. (1996/2005). Työläisperheestä opintielle. Teoksessa Oppiminen ja elämänhistoria./ Life-history Approach to Social Reproduction: Educational Choices among Young Working Class Students. In Antikainen 2005.

Lehtonen, H. \& Tuomisto, J. (1973). Aikuiskoulutus Suomessa: käsitykset ja käyttö. Yhteiskuntatieteiden tutkimuslaitoksen tutkimuksia An:o 45. Tampereen yliopisto.

Mehtätalo, H. (2005). Osallistumattomuuden tekijät. SAK:n luottamushenkilöiden osallistuminen ja osallistumattomuus ammattiyhdistyskoulutukseen. Sosiologian laitoksen raportteja 5. Joensuu: Joensuu University Press.

Moore, E. (2003). Pitkä opintie. Joensuun yliopiston yhteiskuntatieteellisiä julkaisuja 61. (väitöskirja)

Oppiminen ja elämänhistoria. Aikuiskasvatuksen 37. vuosikirja. Aikuiskasvatuksen Tutkimusseura ja Kansanvalistusseura 1996.

Tuijnman, A. \& Hellström, Z. (2001). Curious Minds: Nordic Adult Education Compared. Copenhagen: Nord.

Tuomisto, J. (1998). Market-Oriented Adult Education Policy - A Finnish Perspective. In Alheit, P.\& Kammler, E. (ed.) Lifelong Learning and its Impact o Social and Regional Development. Contributions to the First European Conference on Lifelong Learning. Bremen: Donat.

Vartiainen, P. \& Viiri, A. (2002/2005). Universities and Their Local Partners: The Case of University of Joensuu. Industry \& Higher Education, April 2002. In Antikainen 2005. 